\title{
REVISTAMARACANAN
}

Artigo

\section{Os percursos das Notícias Práticas das Minas de Cuiabá e Goiás na capitania de São Paulo (séculos XVIII-XX)}

\author{
The courses of Notícias Práticas das Minas de Cuiabá e Goiás na capitania de \\ São Paulo (18 ${ }^{\text {th }}-20^{\text {th }}$ Centuries)
}

Maria Aparecida de Menezes Borrego*

Universidade de São Paulo, Brasil

Jean Gomes de Souza**

Universidade de São Paulo, Brasil

Recebido: 04 jun. 2018.

Aprovado: 10 out. 2018.

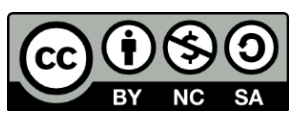

\footnotetext{
Os autores contaram, respectivamente, com o financiamento da Fundação de Apoio à Pesquisa do Estado de São Paulo - FAPESP, modalidade Auxílio à Pesquisa, e do Conselho Nacional de Desenvolvimento Científico e Tecnológico - CNPq, bolsa PIBIC, para a pesquisa que resultou na produção deste artigo.

* Professora do Departamento de Acervo e Curadoria do Museu Paulista e do Programa de Pós-graduação em História Social da Faculdade de Filosofia, Letras e Ciências Humanas da Universidade de São Paulo (USP). Doutora e Mestre em História Social pela USP. (maborrego@usp.br)

ORCID iD: http://orcid.org/0000-0001-5234-6693.

CV Lattes: http://lattes.cnpq.br/1009048665138230.

** Mestrando pelo Programa de Pós-Graduação em História Social da Faculdade de Filosofia, Letras e Ciências Humanas da Universidade de São Paulo. (jean.gomes.souza@usp.br)

ORCID iD: https://orcid.org/0000-0002-0293-2835.

CV Lattes: http://lattes.cnpq.br/7302690995403548.
} 


\section{Resumo}

Os padres Diogo Soares e Domingos Capacci desembarcaram no Rio de Janeiro, em 1730, com a incumbência de elaborarem cartas geográficas e descrições da América Portuguesa a fim de precisarem os limites entre as coroas ibéricas. Para tanto, recolheram narrativas entre sertanistas e monçoeiros que atualmente integram a coleção Notícias práticas de varias minas, e do descobrimento de novos caminhos, e outros sucessos do Brazil, guardada na Biblioteca Pública de Evora. Neste artigo, pretendemos traçar a trajetória das notícias práticas referentes às viagens fluviais de Araritaguaba a Cuiabá em três contextos: de produção, coleta e depósito em Évora no século XVIII; de publicação das notícias avulsas no oitocentos na Revista do Instituto Histórico e Geográfico Brasileiro e reunidas na obra Relatos Monçoeiros, organizada por Afonso de Taunay e editada pela Livraria Martins, por ocasião das comemorações do IV Centenário da cidade de São Paulo em 1954.

Palavras-chave: América Portuguesa. Monções. Manuscrito. Trajetória Editorial.

\section{Abstract}

The priests Diogo Soares and Domingos Capacci arrived at Rio de Janeiro in 1730, with the task of preparing maps and descriptions of the Portuguese America in order to define the boundaries between the Iberian crowns. They collected narratives among sertanistas and monçoeiros that currently comprise the collection Notícias práticas de varias minas, e do descobrimento de novos caminhos, e outros sucessos do Brazil, kept in the Public Library of Évora. In this article, we intend to trace the trajectory of the notícias práticas related to the fluvial trips from Araritaguaba to Cuiabá in three contexts: of production, collection and deposit in Évora in the eighteenth century; of some narratives' editions in the nineteenth century in the Revista do Instituto Histórico e Geográfico Brasileiro and gathered in Relatos monçoeiros, organized by Afonso de Taunay and edited by Martins Editora on the occasion of the celebrations for IV Centenary of São Paulo in 1954.

Keywords: Portuguese America. Monsoons. Manuscript. Editorial Trajectory. 


\section{Introdução}

Diogo Soares e Domingos Capacci, os chamados padres matemáticos, desembarcaram no Rio de Janeiro, em 1730, com a incumbência de produzirem o Novo Atlas da América Portuguesa e uma descrição minuciosa da geografia, vias de comunicações e populações da colônia a fim de precisarem os limites entre as coroas ibéricas. Se as atividades dos jesuítas e as cartas por eles elaboradas já ganharam atenção de pesquisadores, ${ }^{1}$ poucos se debruçaram sobre o conjunto documental textual relativo a Cuiabá que Ihes chegou às mãos com informações sobre o território e seus habitantes para subsidiá-los na produção cartográfica. ${ }^{2}$

O material recolhido entre sertanistas e monçoeiros integra a coleção Notícias práticas de varias minas, e do descobrimento de novos caminhos, e outros sucessos do Brazil, depositada na Biblioteca Pública de Évora (BPE), no códice CXVI 1-15, dividido em quatro grupos documentais distintos: as Notícias Práticas das Minas de Cuiabá e Goiás na capitania de São Paulo (contendo nove notícias); as Notícias Práticas das Minas Gerais do Ouro e Diamantes (contendo cinco notícias); as Notícias Práticas do Novo caminho que se descobriu das campanhas do Rio Grande e Nova Colônia do Sacramento para a vila de Curitiba (contendo três notícias); as Notícias Práticas da Costa, e Povoação do mar do Sul (contendo duas notícias).

É sobre as Notícias Práticas das Minas de Cuiabá e Goiás na capitania de São Paulo que pretendemos nos deter, procurando traçar sua trajetória de produção, circulação e edição nos contextos de coleta na colônia e depósito em Évora no século XVIII, de publicação de narrativas avulsas no oitocentos na Revista do Instituto Histórico e Geográfico Brasileiro e, em conjunto, na obra Relatos Monçoeiros, organizada por Afonso de Escragnolle Taunay, como volume integrante da coleção Biblioteca Histórica Paulista, da Livraria Martins, lançada nas efemérides do IV Centenário da Cidade de São Paulo, em $1954 .^{3}$

As notícias práticas relativas a Cuiabá abordam aspectos das monções, expedições fluviais que se realizaram entre Araritaguaba, hoje Porto Feliz (São Paulo) e Cuiabá (Mato Grosso) ao longo dos séculos XVIII e XIX, cuja rota se tornou regular a partir dos anos de 1720, após o

\footnotetext{
${ }^{1}$ CORTESÃO, Jaime. História do Brasil nos Velhos Mapas. Lisboa: Imprensa Nacional/Casa da Moeda, 2009, 2 tomos; ALMEIDA, André Ferrand. A formação do espaço brasileiro e o projecto do Novo Atlas da América Portuguesa (1713-1748). Lisboa: Comissão Nacional para as Comemorações dos Descobrimentos Portugueses, 2001; BUENO, Beatriz Picolotto Siqueira. Desenho e desígnio: o Brasil dos Engenheiros Militares (1500-1822). São Paulo: EDUSP; FAPESP, 2011.

${ }^{2}$ PRESOTTI, Thereza Martha. Na Trilha das Águas. Índios e Natureza na conquista colonial do centro da América do Sul: Sertões e Minas do Cuiabá e Mato Grosso (século XVIII). 2008. Tese (Doutorado em História) - Universidade Brasília, Brasília.

${ }^{3}$ Cabe dizer que concentraremos nossa análise sobre as notícias relativas às viagens fluviais para as minas de Cuiabá. A notícia referente a Goiás não será alvo deste estudo. Ademais, juntamente com a $5^{a}$ notícia prática, de autoria de Antonio Pires de Campos, ela não foi publicada nos Relatos Monçoeiros, mas sim nos Relatos Sertanistas, também organizados por Afonso de Taunay e publicado na mesma coleção. TAUNAY, Afonso de E. Relatos Monçoeiros. Belo Horizonte; São Paulo: Itatiaia; EDUSP, 1981; TAUNAY, Afonso de E. Relatos Sertanistas. Belo Horizonte; São Paulo: Itatiaia; EDUSP, 1981.
} 
descobrimento do ouro nos barrancos do rio Coxipó e outros afluentes do rio Cuiabá, e compôs uma rede de estradas móveis utilizada para o abastecimento das populações, fundação de vilas, povoamento do território e busca de metais preciosos.

Para reconstituir a trajetória social e editorial das Notícias Práticas nos valeremos sobretudo das análises empreendidas por António Castillo Gómez sobre os tempos do escrito produção, uso e conservação; por Roger Chartier e Fernando Bouza sobre a permanência e a relevância dos manuscritos na era dos impressos e as múltiplas autorias dos textos; por Kapil Raj sobre a circulação de saberes na época moderna e a transformação do conhecimento a cada apropriação. ${ }^{4}$

Para além das contribuições dos estudiosos da cultura escrita e da circulação em tempos de mundialização, o itinerário das Notícias Práticas terá como alicerce a perspectiva da cultura material adotada por Samuel Alberti para compreender as três fases na vida dos objetos musealizados: a coleta e sua proveniência, a vida na coleção, a visão do objeto. ${ }^{5}$

Tomadas como artefatos, as narrativas em tela, produzidas em solo colonial, chegaram às mãos do padre Soares; foram enviadas a Évora; de lá regressaram por meio da transcrição em material impresso e serviram para novas e velhas interpretações, mediando relações pessoais e institucionais em contextos políticos, historiográficos e editoriais distintos. Ainda que classificadas primordialmente como documentos textuais, sua materialidade nos impele a considerá-las como produtos e vetores de relações sociais na célebre expressão de Ulpiano Bezerra de Meneses. ${ }^{6}$

\title{
A reunião das Notícias Práticas pelo padre Diogo Soares
}

Na provisão passada aos dois padres jesuítas, datada de 18 de novembro de 1729, o rei D. João $\mathrm{V}$ os instrui a elaborarem cartas geográficas do território brasileiro

\begin{abstract}
tomando para isso noticia da gente pratica da terra; porque se the agora não tem havido devisa regular principalmente pelos certões, ficando essa materia quasi toda no arbítrio das gentes que forão povoando, porem sempre deveis apontar por linhas as devisões que por ora se praticão, como também as que vos parecerem que são mais comodas e tem mais certa devisão pelos rios, montes e serranias, signalando os Lemites que estão em practica com linhas de hûa cor, e os que vos parecerem melhor com linhas de outra.?
\end{abstract}

\footnotetext{
${ }^{4}$ BOUZA, Fernando. Corre manuscrito: una historia cultural del Siglo de Oro. Madrid: Marcial Pons, 2001; CHARTIER, Roger. Os desafios da escrita. São Paulo: Ed. UNESP, 2002; CASTILLO GÓMEZ, Antonio. Historia de la cultura escrita: ideas para el debate. Revista Brasileira de História da Educação, Maringá, n. 5, 93-124, jan./abr. 2003; RAJ, Kapil. Além do Pós-colonialismo... e Pós-positivismo. Trad.: Juliana Freire. Revista Maracanan, Rio de Janeiro, n. 13, 164-175, dez. 2015.

${ }^{5}$ ALBERTI, Samuel J. M. M. Objects and the Museum. Isis Focus, v. 96, n. 4, 559-571, 2005.

${ }^{6}$ MENESES, Ulpiano T. Bezerra de. Memória e cultura material: documentos pessoais no espaço público. Estudos Históricos, Rio de Janeiro, n. 21, 80-103, $1^{\circ}$ sem. 1998.

7 Provisão de D. João V aos "Padres Matemáticos" Diogo Soares e Domingos Capacci, com as instruções para seu trabalho no Brasil. Arquivo Histórico Ultramarino (AHU), cód. 248 do Conselho Ultramarino, fl. 249v-250, apud CORTESÃO, Jaime. História do Brasil... Op. cit., p. 229-230.
} 
As referências à "gente prática", às "divisões que ora se praticam", aos "limites que estão em prática" equivalem às três acepções dadas à palavra e a suas variações por Raphael Bluteau no Vocabulário português e latino, de 1720: em primeiro lugar, prática é "o exercício, colocar em prática os preceitos de uma arte", ou seja, decorre de ações habituais e frequentes. Em segundo lugar, é "uso, costume, estilo". E, por fim, homem prático é o homem "experimentado, versado, perito". ${ }^{8}$

Serge Gruzinski, ao definir quem eram esses homens que os portugueses chamavam de práticos, os define exatamente pelo contato com aquilo que eles escreviam, com aquilo que eles puderam adquirir conhecimento de causa: "Seu objetivo é informar, mas sempre com fins práticos e políticos. Esses experts nunca são pesquisadores enclausurados em seus gabinetes de trabalho. Todos, porém, são homens que empunham penas, único meio de fixar e transmitir sua experiência". ${ }^{9}$

Aliás, cabe lembrar como bem o fez André Ferrand de Almeida que, no começo do século XVIII, D. João $\mathrm{V}$ e o Conselho Ultramarino já haviam recomendado às autoridades da capitania de São Paulo o envio de engenheiro e pessoas práticas, nomeadamente paulistas sertanejos, aos sertões até então considerados portugueses, denunciados pelo ouvidor Rafael Pires Pardinho, em 1717, como alvo dos avanços dos jesuítas espanhóis, a fim de encontrarem balizas naturais para definirem os limites entre as duas coroas ibéricas na América. ${ }^{10}$

A questão da oficialização do território da América portuguesa, sobretudo das fronteiras com a Espanha, ganhou fôlego a partir de 1720 com a publicação de Détermination géographique de la situation et de l'étendue des différentes parties de la Terre, de autoria de Guillaume Delisle, geógrafo do rei da França. Nesse trabalho, por meio dos mapas de Delisle, ficou perceptível o quanto os portugueses haviam avançado para além da linha de Tordesilhas, reacendendo o debate sobre a necessidade de se cartografar e reconhecer os limites dos impérios em disputa. ${ }^{11}$

O conselho do rei pela busca de notícias produzidas por "gente prática da terra" evidencia, por um lado, sua circulação nos meios político-administrativos, sociais e culturais da colônia antes do envio dos padres matemáticos e, por outro, a importância atribuída aos sertanistas, até então as principais fontes para determinados espaços geográficos, como já apontou Mario Clemente Ferreira. ${ }^{12}$

\footnotetext{
${ }^{8}$ BLUTEAU, Raphael. Vocabulario portuguez \& latino: aulico, anatomico, architetonico... Coimbra: Collegio das Artes da Companhia de Jesus, 1720, v. 6, p. 674.

${ }_{9}^{9}$ GRUZINSKI, Serge. As quatro partes do mundo: história de uma mundialização. Belo Horizonte; São Paulo: Ed. UFMG; EDUSP, 2014, p. 191.

${ }^{10}$ ALMEIDA, André Ferrand de. Os jesuítas matemáticos e os mapas da América portuguesa (17201748). Oceanos - A formação territorial do Brasil, Lisboa, n. 40, out./dez. 1999, p. 79-92. Entre os estudos pioneiros sobre a atuação dos padres matemáticos em solo colonial, destaca-se: CORTESÃO, Jaime. A missão dos padres matemáticos no Brasil. Lisboa: Agência Geral do Ultramar, 1958.

${ }^{11}$ CORREA, Jessica Aparecida. O Novo Atlas da América Portuguesa e a oficialização do território colonial (1730-1749). Boletim Gaúcho de Geografia, v. 42, n. 2, 1-21, 2016, p. 1-21.

${ }_{12}$ FERREIRA, Mario Clemente. Colonos e Estado na revelação do espaço e na formação territorial de Mato Grosso no Século XVIII: notas de uma investigação. Actas do Congresso Internacional Espaço Atlântico de Antigo Regime: poderes e sociedades. Lisboa, 2005, p. 1-13.
} 
O trânsito das Notícias Práticas parece inserir-se no quadro maior do movimento dos manuscritos na Época Moderna ensejado por relações pessoais analisado por Fernando Bouza na Espanha seiscentista e por Maria Lêda Oliveira no contexto colonial onde a proibição da instalação da imprensa acabou por estimular a circulação, o empréstimo e a cópia de livros escritos à mão. ${ }^{13} \mathrm{~A}$ recorrência aos práticos, além disso, atesta o reconhecimento real dos saberes geográficos locais para percepção e ocupação do território não só num período anterior à vinda de especialistas portugueses e estrangeiros para o esquadrinhamento cartográfico da América, mas servindo-Ihes inclusive de manancial informativo. ${ }^{14}$

Tal realidade é confirmada por uma carta enviada por Soares ao soberano, datada de 4 de julho de 1730, apenas cinco meses após sua chegada ao Rio de Janeiro, em que informava que

tenho já junto uma grande cópia de noticias, vários Roteyros e Mapas dos melhores certanistas de S. Paulo e Cuyabá, Rio Grande, e da Prata, e vou procurando outras a fim de dar principio a algûa carta, porque as estrangeiras andam erradíssimas, não só no que toca ao Sertão mas inda nas Alturas e Longitudes de toda esta Costa. ${ }^{15}$

Mas quais informações continham os documentos e quais eram seus autores para que o padre pudesse reuni-las por critérios geográficos em conjuntos nomeados Notícias Práticas?

Quadro 1 - Notícias práticas sobre os caminhos entre São Paulo e Cuiabá, na Biblioteca Pública de Évora

- Noticia $1^{a}$ Pratica que dá ao R. P. Diogo Soares o Capitão Antonio Cabral Camello sobre a viagem que fez ás Minas de Cuyabá no anno de 1727 (escrita por João Antônio Cabral Camelo em 1734, publicada no tomo IV da RIHGB em 1842 a partir do manuscrito oferecido por Francisco Adolfo de Varnhagen e nos Relatos Monçoeiros em 1953 e 1981).

- Noticia 2a Pratica do que Ihe soccedeo na volta que fez das mesmas Minas de S. Paulo (escrita por João Antônio Cabral Camelo em 1734 e publicada nos Relatos Monçoeiros em 1953 e 1981).

- Noticia $3^{a}$ Pratica, dada pelo Capitão Domingos Lourenço de Araujo ao R. P. Diogo Soares sobre o infeliz successo que tiveram no Rio Paraguay as tropas, que vinham para S. Paulo no anno de 1730 (escrita por Domingos Lourenço de Araújo em 1730 e publicada nos Relatos Monçoeiros em 1953 e 1981).

\footnotetext{
13 "Assim sendo, boa parte da produção escrita relativa ao Brasil feita em língua portuguesa nos séculos XVI e XVII circulou entre os letrados através de cópias manuscritas que passavam de mãos em mãos. Não era necessário uma obra ser editada para ser conhecida, lida e usada; bastava apenas saber-se da sua existência e ter-se acesso ao texto, por exemplo através de relações pessoais". OLIVEIRA, Maria Lêda. A História do Brazil de frei Vicente do Salvador. História e política no Império português do século XVII. Rio de Janeiro; São Paulo: Versal; Odebrecht, 2008, p.11.

${ }^{14}$ Sobre a apropriação dos conhecimentos indígenas pelos colonos na ocupação do território americano, ver os instigantes capítulos Veredas de pé posto e Samaritanas do sertão em Caminhos e fronteiras. Cf.: HOLANDA, Sérgio Buarque de. Caminhos e fronteiras. 3a ed. São Paulo: Companhia das Letras, 1994.

${ }^{15}$ Carta de 4 de julho de 1730. AHU, Documentos Avulsos, Rio de Janeiro, 1730, apud ALMEIDA, André Ferrand de. Os jesuítas matemáticos e... Op. cit., 1999, p.89.
} 
- Noticia $4^{a}$ Pratica, vinda da cidade do Paraguay a Nova Colonia do Sacramento com aviso da venda que fizeram os Payaguaz dos Captivos Portuguezes naquella mesma Cidade, e escripta por D. Carlos de los Reis Valmaseda (escrita por D. Carlos de los Reyes Valmaseda em 1730 e publicada nos Relatos Monçoeiros em 1953 e 1981).

- Noticia 5a Pratica, dada pelo Capitão Antonio Pires de Campos ao Capitão Domingos Lourenço de Araujo, e communicada por este ao R. P. Diogo Soares sobre os Reinos e Nações de Barbaros, que ha na derrota e viagem do Cuyabá, e seu reconcavo (dada por Antônio Pires de Campos entre 1727 e 1730, publicada no tomo XXV da RIHGB em 1862 publicada nos Relatos Sertanistas em 1953 e 1981).

- Noticia 6a Pratica, e relação verdadeira da derrota e viagem, que fez da Cidade de S. Paulo para as Minas do Cuyabá o Exmo. Sr. Rodrigo Cezar de Menezes, Governador e Capitão General da Capitania de S. Paulo, e suas Minas descobertas no tempo de seu governo, e nelle mesmo estabelecidas (escrita por Gervásio Leite Rebelo em 1727 e publicada nos Relatos Monçoeiros em 1953 e 1981).

- Noticia 7a Pratica, e Roteiro verdadeiro das Minas do Cuyabá, e de todas as suas marchas, cachoeiras, itaipavas, varadouros, e descarregadouros das Canoas, que navegam para as ditas Minas, com os dias de navegação, e traveça, que costumam fazer por mar e terra (escrita por Manuel de Barros entre 1728 e 1741 e publicada nos Relatos Monçoeiros em 1953 e 1981).

- Noticia 8a Pratica, exposta na copia de uma Carta escripta do Cuyabá aos novos pretendentes daquellas Minas (escrita por Francisco Palacio em 1726 e publicada em Relatos Monçoeiros em 1953 e 1981).

Fonte: RIVARA, Joaquim Heliodoro da Cunha. Catalogo dos Manuscriptos da Biblioteca Publica Eborense. Lisboa: Imprensa Nacional, 1850, p. 191-193.

Dada a heterogeneidade pela qual primavam a autoria e a natureza das narrativas, as intencionalidades da escrita e definição dos destinatários, é de se supor que tenham sido assim reunidas pelo fato dos autores, embora nem todos, terem sido considerados por Diogo Soares como homens práticos, experientes nas monções, atendendo às demandas contidas na instrução régia que recebera. Nem todos, pois D. Carlos de los Reyes Valmaseda, autor da quarta notícia, uma carta em castelhano, era funcionário da Coroa espanhola, e o português Gervásio Leite Rebelo, autor da sexta - uma Relação provavelmente endereçada ao rei - era secretário de governo de Rodrigo César de Meneses.

João Cabral Camelo e Domingos Lourenço de Araujo, autores das três primeiras notícias eram mercadores; Antonio Pires de Campos, autor da quinta notícia, pertencia a uma família de sertanistas de Itu; a Manuel de Barros, da sétima notícia, creditam as atividades de sertanista e de engenheiro; e o autor anônimo da oitava notícia tem sido identificado como Francisco Palácio, cuja biografia é praticamente desconhecida, mas acredita-se ter proximidade com a Igreja em razão das imagens e expressões utilizadas no relato. ${ }^{16}$

Contudo, é bem provável que os autores tivessem se encontrado nas minas de Cuiabá, pois suas narrativas estão de alguma forma próximas da data de fundação da Vila de Bom

${ }^{16}$ PRESOTTI, Thereza Martha. Na Trilha das Águas... Op. cit., p. 131-172. 
Jesus do Cuiabá, em 1727, envolvidos com as disputas políticas entre o governador Rodrigo César de Meneses e o ouvidor Antonio Alvares Lanhas Peixoto ou com o ataque dos Payaguá à monção do Ouvidor em direção a Araritaguaba, em junho de 1730, que culminou com sua morte e de dezenas de acompanhantes. ${ }^{17}$

Talvez tenha sido a repercussão das notícias sobre este grave incidente no momento de sua chegada à colônia que motivara o padre Diogo Soares a encomendar notícias a João Cabral Camelo, integrante da fatídica monção de Lanhas, e a Domingos Lourenço de Araujo, passageiro da expedição fluvial seguinte, que recolhera informações sobre o ataque a partir de sobreviventes encontrados pelo caminho. Antonio Pires de Campos foi outro a quem se solicitara a produção de notícia, porém com esse sertanista Diogo Soares não teve contato, pois o relato chegou ao padre por intermédio do mesmo Domingos Lourenço de Araujo, que foi inclusive o anotador da quinta notícia.

Como desconhecemos quando e de que forma as notícias chegaram às mãos de Diogo Soares, não podemos afirmar qual foi o critério por ele adotado para a numeração dos relatos, mas podemos assegurar que não foi por ordem de entrega, nem cronológica, dado o fato de que o texto escrito por Gervásio Leite Rebelo no começo de 1727 consta como 6a notícia prática e os redigidos por João Cabral Camelo, datados de 1734 , correspondem às $1^{\mathrm{a}}$ e $2^{\mathrm{a}}$ Notícias práticas. Podemos, porém, assegurar que foi o próprio padre Diogo Soares quem as numerou, as intitulou e as modificou.

A $8^{a}$ oitava notícia é uma evidência das alterações realizadas pelo jesuíta ao transcrever o texto que lhe chegou às mãos atribuído a Francisco Palacio, quando comparamos um testemunho deste relato, guardado no Arquivo do Instituto de Estudos Brasileiros (IEB), da Universidade de São Paulo, com a mesma notícia depositada na Biblioteca Pública de Évora (BPE) escrita com seu punho.

Quadro 2 - Comparação entre trechos dos diferentes testemunhos do relato de Francisco Palacio

\begin{tabular}{|c|c|}
\hline Instituto de Estudos Brasileiros & Biblioteca Pública de Évora \\
\hline $\begin{array}{l}\text { A quem senão a vos Irmãos meos, } \\
\text { perseguidos da fortuna e de sua perseguiçam } \\
\text { dezesperados. A quem senão avos fareis } \\
\text { avizo dos innumeraveis perigos desta } \\
\text { viagem. }{ }^{18}\end{array}$ & $\begin{array}{l}\text { A quem senaõ avos, amigos meos per } \\
\text { seguidos da fortuna, e da desgraça, aquem } \\
\text { se naõ avos farei agora este avizo, oudarei a } \\
\text { triste súma dos inumeraveis perigos desta } \\
\text { Viage. }{ }^{19}\end{array}$ \\
\hline
\end{tabular}

\footnotetext{
17 Sobre o conturbado cenário político que marcou a fase inicial da ocupação portuguesa nas minas de Cuiabá, ver: CANAVARROS, Otávio. O poder metropolitano em Cuiabá (1727-1752). Cuiabá: Ed. UFMT, 2004; FERNANDES, Luís Henrique Menezes. Um governo de engonços. Metrópole e sertanistas na expansão dos domínios portugueses aos sertões do Cuiabá (1721-1728). Curitiba: Prismas, 2015.

${ }^{18}$ Roteyro da viagem de São Paulo para as Minas do Cuyaba que fez Francisco Palacio no anno de 1726. Instituto de Estudos Brasileiros, Acervo Yan de Almeida Prado, cód. 31, f. 2.

${ }^{19}$ Noticia 8 a Practica. Exposta na copia de huã carta escrita do Cuyabâ, aos novos pertendentes daquellas Minas. Biblioteca Pública de Évora, Coleção Diogo Soares, cód. CXVI 1-15, f. 122.
} 


\begin{abstract}
Itaypâbas sam muitas paragens que o rio tem secas, em as mais dellas encalham as canoas, e a poder de forças debraço as levam as mãos the seporem onde possão navegar; cujos Lugares saõ de muita utilidade às pessoas calidas, por que ahí tomam banhos a sua; ou contra sua vontade;

[O parágrafo continua ainda por três linhas até chegar ao trecho a seguir]

Pedras soltas em rio morto: saõ huns sexos muito grandes, que estam sós em muitas paragens; e como a agoa nelles naõ faz reçolho, sinal que de longue se possa ver, por estarem com esta cubertos naõ hê fácil o desviar se desta diabrura, e por esta razam se emborcam alguas canoas, cujos Lugares sam fundos, e somente a boa vigilancia dos proeyros pode acudir, e evitar algum mao acontecimento de emborcaçam. ${ }^{20}$
\end{abstract}

Itaipavas saõ algũas parages, ou pasos, q o rio tem muito secos, nas mais dellas encalhaõ as canoas, e só apoder deforça selivraõ dellas; porq cómumente selevaõ as mãos athe seporem em parte em que possaõ navegar.

Pedras soltas em Rio morto, saõ huns seixos muito grandes q estaõ sós, e separados em muitas. evarias partes do rio, e como aagoa nelles naõ fas recolho, sinal para sepoderem ver delonge, pelos ter cobertos amesma agoa, naõ hê facil o eitalos: razaõ porq se emborcaõ nelles muitas canoas, eseperdem muitas fazendas, quando naõ hê com ellas a Vida. ${ }^{21}$

Como se vê, a mediação editorial de Diogo Soares é perceptível, não só na seleção e recolha do material, mas também na troca de léxicos, supressão de palavras e de trechos, inversão de sentenças e mudanças de pontuação, o que sugere que o jesuíta retinha aquilo que lhe era conveniente para a construção dos mapas ou para o atendimento à provisão régia e dispensava o que lhe parecesse supérfluo.

As Notícias Práticas das Minas de Cuiabá e Goiás na capitania de São Paulo reunidas pelo padre Diogo Soares correspondem a 167 fólios do códice CXVI 1-15 da Biblioteca Pública de Évora. O conjunto textual foi composto por dois escribas distintos. A diferença entre os punhos é clara e foi determinada a partir da análise empreendida acerca de elementos como a morfologia das letras, o traçado, o ângulo, o módulo e o peso do instrumento de escrita sobre o papel. Comparando os fólios das Notícias Práticas com a caligrafia de duas cartas assinadas por Diogo Soares e remetidas a Martinho de Mendonça em 1734 e 1735, guardadas no Arquivo Nacional da Torre do Tombo, encontramos muitas semelhanças, o que tornou possível identificar o jesuíta matemático como um dos escribas. ${ }^{22}$

\footnotetext{
${ }^{20}$ Roteyro da viagem de São Paulo para as Minas do Cuyaba que fez Francisco Palacio no anno de 1726. Acervo Yan de Almeida Prado, Instituto de Estudos Brasileiros, códice 31, f. 2.

${ }^{21}$ Noticia 8 a Practica. Exposta na copia de huã carta escrita do Cuyabâ, aos novos pertendentes daquellas Minas. Coleção Diogo Soares, Biblioteca Pública Eborense, códice CXVI 1-15, f. 123.

${ }_{22}$ Cartas de Diogo Soares a Martinho de Mendonça de Pina e Proença de 19 de dez. de 1734 e 12 de fev. de 1735. Arquivo Nacional Torre do Tombo (ANTT), Manuscritos do Brasil, L. 11, f. $38 ; 43$.
} 
Quadro 3 - Quadro comparativo de palavras presentes na $1^{\text {a }}$ notícia no códice CXVI 1-15 da BPE e nas cartas de Diogo Soares a Martinho de Mendonça em 1734 e 1735
1) 8 ioge

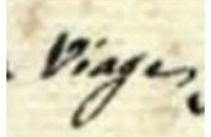
Viage
F1. 1 Noticias Práticas
Carta de $12 / 02 / 1735$
2)
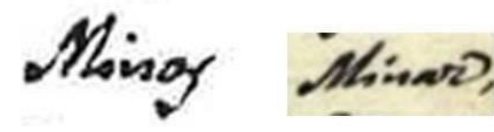
Minas/Minaz
F1.1 Noticias Práticas
Carta de $12 / 02 / 1735$
3)
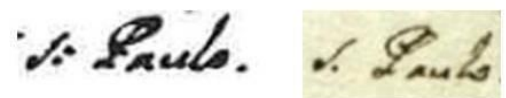
$\underline{\text { S. Paulo }}$
F1. 6 Notícias Práticas
Carta de 19/12/1734
4)
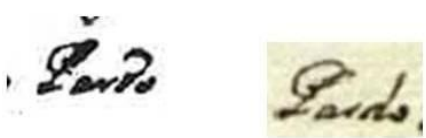
$\underline{\text { Pardo }}$
F1. 2 Notícias Práticas
Carta de 19/12/1734

No códice em questão há dois testemunhos das oito Notícias Práticas das Minas de Cuiabá e Goiás na capitania de São Paulo, um cujo o autor material é o padre matemático (que nomeamos de testemunho "A") e o outro, um escriba desconhecido (nomeado como "B"). No testemunho A estão ausentes os três primeiros parágrafos da $3^{a}$ notícia, dada por Domingos Lourenço de Araujo, além do próprio título do texto: passa-se do final da $2^{a}$ notícia, dada por Cabral Camelo (fólio 10) para o quarto parágrafo da $3^{a}$ notícia (fólio 11). No testemunho $B$ todas as notícias foram recopiadas, porém, neste caso, a $3^{a}$ consta de forma integral. Isso nos leva a crer que a existência do segundo testemunho dos textos no mesmo códice possa estar vinculada à tentativa de correção do possível erro cometido por Diogo Soares que, no momento da transcrição do manuscrito original, enviado por Domingos Lourenço de Araujo, não a fez por completo.

Com a morte de Capacci em 1736 e a de Diogo Soares em 1748, o Novo Atlas da América Portuguesa ficou inacabado, sem mapas da região das minas de Cuiabá, para onde Soares nunca chegara a ir. Entretanto, tal como assevera Presotti, a instrução régia de se juntar aos mapas um minucioso levantamento das condições dos caminhos fluviais e terrestres e da ocupação colonial e indígena talvez tenha sido cumprida por meio da formação da coleção das Notícias Práticas que, de fato, chegaram a Portugal. ${ }^{23}$

Embora não saibamos o itinerário percorrido pelas Notícias Práticas da colônia ao reino podemos arriscar traçar seus percursos com base na formação das bibliotecas portuguesas e de seus idealizadores nos séculos XVIII - pós-terremoto de Lisboa (1755) - e inícios do XIX.

\footnotetext{
${ }^{23}$ PRESOTTI, Thereza Martha. Na Trilha das Águas... Op. cit., p. 134.
} 
Conjecturamos que as Notícias Práticas tenham deixado a América Portuguesa após 1748, quando falecera Diogo Soares. Como o cartógrafo fora professor do Colégio Espírito Santo dos inacianos de Évora, é possível que os manuscritos tenham sido enviados para a Livraria e Casa dos Jesuítas eborenses. ${ }^{24}$ Entretanto, em face da constituição da Biblioteca da Real Mesa Censória, idealizada por D. Frei Manuel do Cenáculo Villas Boas, o Marquês de Pombal ordenou, em 1774, que "se transportassem para a Alfândega da cidade de Lisboa, com direção à Real Meza Censória, os livros pertencentes aos denominados Jesuítas das Ilhas da Madeira, e Açores, dos Collegios do Faro, Portimão, Évora, Elvas, e Villa Viçoza". ${ }^{25}$

Se as Notícias Práticas foram de Évora a Lisboa, é provável que tenham saído da capital anos depois juntamente com outros tantos livros impressos e manuscritos carregados por Cenáculo, quando este fora assumir o cargo de Bispo de Beja após o consulado pombalino. Os desvios de obras, sobretudo livros, por parte de Frei Cenáculo foi documentado por um dos seus correspondentes, Alexandre Faria Manuel, secretário da Real Mesa Censória. ${ }^{26}$ Nesta cidade, o frei bibliófilo não só fundou uma biblioteca pública como doou de seu acervo pessoal, em 1797, noventa caixotes de livros para a futura Real Biblioteca Pública da Corte, hoje Biblioteca Nacional de Portugal, originada da Real Mesa Censória. ${ }^{27}$

Em 1803, já o encontramos como Arcebispo de Évora, para onde também levara caixotes e mais caixotes de livros, contabilizados em milhares de volumes. Dois anos depois, a Biblioteca Pública de Évora seria inaugurada sob seus auspícios. Os fundos iniciais da instituição eram provenientes dos livros deixados por D. Joaquim Xavier Botelho de Lima, antecessor de Cenáculo, e pelos incontáveis materiais manuscritos e impressos que ele próprio trouxera de Beja. ${ }^{28}$

Segundo Francisco Antonio Vaz, os manuscritos da Biblioteca tiveram diversas procedências: do Colégio Espírito Santo, pertencente à Universidade de Évora, foram remetidos poucos documentos, como livros de atos públicos, já que o grosso do fundo dos jesuítas havia sido transferido para a Mesa Censória após a expulsão dos jesuítas, como comentado anteriormente; dos fundos das bibliotecas conventuais (Cartuxa, São Francisco, São Domingos etc.), incorporados após 1834, com a extinção das ordens religiosas; da coleção Manisola da Casa do Visconde da Esperança, integrados após 1955; e finalmente da coleção

\footnotetext{
${ }^{24}$ ROSA, Teresa Maria Rodrigues da Fonseca. História da Universidade Teológica de Évora (Séculos XVI a XVIII). Lisboa: Instituto de Educação da Universidade de Lisboa, 2013, p. 190.

${ }^{25}$ ANTT, Lisboa - Min. Reino, L. 362, f. 171v-172, apud DOMINGOS, Manuela. Para a história da Real Mesa Censória. Separata da Revista da Biblioteca Nacional. Lisboa, s. 2, v. 7, n. 1, 1992, p. 140. Como testemunhou Bento Farinha, o espólio do Colégio do Espírito Santo foi transferido para Real Mesa Censória em 1775. Grifo nosso.

${ }^{26}$ Cf.: VAZ, Francisco Antonio Lourenço (coord.). Correspondência Inédita dirigida a D. Frei Manuel do Cenáculo - As cartas de Joaquim Sá e Alexandre Faria Manuel. Évora: CIDEHUS-UE, 2015.

27 DOMINGOS, Manuela; MONTEIRO, Ana Isabel Líbano. "Casa dos Livros de Beja": doação de Frei Manuel do Cenáculo à Real Biblioteca Pública da Corte: mostra bibliográfica, 1 de Março - 13 de Maio de 2006 / Biblioteca Nacional. Lisboa: Biblioteca Nacional, 2005.

${ }^{28}$ VAZ, Francisco Antonio Lourenço de. A Fundação da Biblioteca Pública Evorense. In: VAZ, Francisco Antonio Lourenço de; CALIXTO, José António (coords.). Frei Manuel do Cenáculo: Construtor de Bibliotecas. Évora: [s.n.], 2005.
} 
particular de Frei Manuel do Cenáculo, à qual aventamos terem pertencido as Notícias Práticas, núcleo mais plausível frente aos demais arrolados.

A certeza de sua existência na biblioteca eborense somente se dará quando passam a figurar no Catálogo dos Manuscritos da Biblioteca Pública Eborense, organizado por iniciativa de Joaquim Heliodoro da Cunha Rivara, bibliotecário que ficou à frente da instituição de 1838 a 1855, justamente no contexto em que Francisco Adolfo de Varnhagen teve acesso a elas.

\section{Varnhagen descobre as narrativas monçoeiras}

Das oito Notícias Práticas concernentes a Cuiabá, duas delas vieram a público na Revista do Instituto Histórico e Geográfico Brasileiro (RIHGB) nos anos de 1842 e 1862: $1^{\text {a }}$ e $5^{a}$ notícias práticas, dadas respectivamente por João Antônio Cabral Camelo e Antônio Pires de Campos. Tais publicações foram fruto do esforço do Instituto Histórico e Geográfico Brasileiro (IHGB) em recolher, colecionar e divulgar documentos considerados importantes para a construção da história pátria.

Fundado em outubro de 1838, o IHGB, assim como instituições congêneres, tinha por objetivo "construir uma história da nação, recriar um passado, solidificar mitos de fundação, ordenar fatos buscando homogeneidades em personagens e eventos até então dispersos". ${ }^{29}$ Para isso, a recolha de documentos relativos ao Brasil se mostrou mais que necessária.

Em sessão realizada em 17 de dezembro de 1838, o primeiro-secretário perpétuo, Cônego Januário da Cunha Barbosa, leu aos presentes um texto autoral intitulado Lembrança do que devem procurar nas províncias os sócios do Instituto Histórico Brasileiro, para remetterem à sociedade central do Rio de Janeiro, no qual enumerava cada um dos tipos documentais importantes para a construção da história do Brasil: notícias biográficas; cópias autênticas de documentos interessantíssimos à história antiga e moderna do Brasil; notícias sobre os costumes dos índios, catequese, aumento e diminuição das populações indígenas; descrição do comércio praticado nas províncias e de seus principais produtos; notícias de fatos extraordinários (fenômenos naturais dignos de menção); notícias sobre fauna, flora e minerais. ${ }^{30}$

Em 1839 foram iniciadas as discussões acerca da necessidade de criação de uma missão de pesquisa documental em arquivos da Europa que detivessem sob a sua guarda manuscritos relativos ao Brasil, valendo-se para isso do orçamento do Ministério dos Negócios Estrangeiros. Para o cargo de adido de primeira classe, cujas atribuições eram pesquisar, transcrever e mandar copiar documentos notáveis, José Maria do Amaral foi o primeiro nomeado. Este, por sua vez, pouco correspondeu às expectativas de exercício do cargo e foi

\footnotetext{
${ }^{29}$ SCHWARCZ, Lilia Moritz. O espetáculo das raças: cientistas, instituições e questão racial no Brasil (1870-1930). São Paulo: Companhia das Letras, 1993, p. 129.

${ }^{30}$ BARBOSA, Januário da Cunha. Lembrança do que devem procurar nas províncias os sócios do Instituto Histórico Brasileiro, para remetterem à sociedade central do Rio de Janeiro. Revista do Instituto Histórico Geográfico Brasileiro (RIHGB), t. I, 1839, p. 109-110.
} 
substituído em maio de 1842. Francisco Adolfo de Varnhagen que, na época contava 26 anos, foi nomeado como o seu sucessor. Membro da Academia Real das Ciências de Lisboa e sócio correspondente do IHGB, desde a sua admissão no Instituto em 1840 se dedicava à pesquisa documental junto a Amaral, quando nem designado para o cargo havia sido. ${ }^{31}$

Para além do objetivo específico de coletar documentos para a escrita da história do Brasil, as missões de pesquisadores do IHGB no exterior "deveriam colher subsídios que auxiliassem o governo na demarcação dos limites da soberania do país". ${ }^{32}$ O que estava em jogo no período era o próprio projeto de construção da nação brasileira a partir dos esforços centralizadores do Rio de Janeiro, de modo que o conhecimento dos próprios limites do território era uma das condições básicas para que a desejada integração territorial ocorresse. ${ }^{33}$ Outra questão que se colocava era a da delimitação das fronteiras frente aos países vizinhos anteriormente colonizados pelos espanhóis, o que motivou o ministro dos Negócios Estrangeiros, Aureliano Coutinho, a sugerir que o Instituto enviasse uma petição à Câmara dos Deputados para autorizar que seu ministério enviasse à Espanha e aos países próximos um diplomata a fim de coligir e remeter ao Brasil documentos importantes para a sua história. ${ }^{34}$

Consta na publicação da $1^{\text {a }}$ notícia prática, no tomo IV da RIHGB (1842), a indicação de que o manuscrito em questão fora oferecido pelo sócio correspondente Francisco Adolfo de Varnhagen. Além do interesse em contribuir com a instituição na qual havia sido recentemente aceito, há, também, uma dimensão de cunho pessoal no oferecimento desse manuscrito, registrado na própria carta enviada ao Cônego Januário, uma vez que era nascido em São João de Ipanema (atual Iperó), região de Sorocaba e das monções: "Esta collecção de roteiros será além d'isso um monumento à minha Província pela distincta parte que n'essas excursões tiveram os nossos ousados paulistas". ${ }^{35}$

Sabemos que o contato de Varnhagen com o códice das Notícias Práticas precedeu a sua nomeação como funcionário da missão no exterior. Em carta enviada de Lisboa, em 16 de março de 1842, a Joaquim Heliodoro da Cunha Rivara, diretor da Biblioteca Pública de Évora, informou que estava em posse do "livro manuscrito das minas de Cuiabá" e que o material

\footnotetext{
${ }^{31}$ GUIMARÃES, Manuel Luiz Salgado. Nação e Civilização nos Trópicos: o Instituto Histórico Geográfico Brasileiro e o projeto de uma história nacional. Revista Estudos Históricos, Rio de Janeiro, v. 1, n.1, 5-27, 1988; WEHLING, Arno. Estado, história, memória: Varnhagen e a construção da identidade Nacional. Rio de Janeiro: Nova Fronteira, 1999; GUIMARÃES, Lucia Maria Paschoal. Debaixo da imediata proteção imperial. São Paulo: Annablume, 2011, p. 90-91; CEZAR, Temístocles. Varnhagen em movimento: breve antologia de uma existência. Topoi, Rio de Janeiro, v. 8, n. 15, jul./dez. 2007, p. 169. Até 1864, período em que a missão foi extinta, Varnhagen foi sucedido por Joaquim Caetano da Silva, Gonçalves Dias e João Francisco Lisboa. Cf.: CORRÊA FILHO, V. Missões brasileiras nos arquivos europeus. RIHGB, Rio de Janeiro, n. 213, 1951.

32 GUIMARÃES, Lucia Maria Paschoal. Debaixo da imediata... Op. cit., p.88.

${ }^{33}$ Naquele contexto, refletir sobre a formação da identidade nacional pressupunha não só a questão da integração territorial, mas também a incorporação das populações indígenas espalhadas pelo país. Sobre essa temática abordada no IHGB, ver: TURIN, Rodrigo. Tessituras do tempo: discurso etnográfico e historicidade no Brasil oitocentista. Rio de Janeiro: Nova Fronteira, 1999; KODOMA, Kaori. Os índios no Império do Brasil. A etnografia do IHGB entre as décadas de 1840 e 1860 . Rio de Janeiro; São Paulo: Ed. Fiocruz; EDUSP, 2009.

${ }^{34}$ GUIMARÃES, Lucia Maria Paschoal. Debaixo da imediata... Op. cit., p. 89.

${ }^{35}$ Carta de Francisco Adolfo de Varnhagen ao Cônego Januário da Cunha Barbosa. S/d. RIHGB, t. 5, 1843, p. 93. Grifos nossos.
} 
possuía novidade em algumas das relações nele inscritas e que estas encontravam-se em duplicata no códice, informação que, segundo Varnhagen, Rivara deveria registrar no catálogo da Biblioteca que estava a compor - o que, de fato, o diretor fez. ${ }^{36} \mathrm{O}$ seu interesse em copiar parte dos relatos que ali se encontravam é perceptível por meio de uma insinuação dirigida ao interlocutor: "Estou lendo com toda a attenção e tirando minhas notas, e em alguns lugares tinha vontade de tirar mais que notas, mas não me atrevo, porque não pedi nem tenho para isso concessão de V. Sa, de cujo favor não devo abusar". ${ }^{37}$

Por meio das cartas subsequentes nota-se que Rivara concedeu a Varnhagen autorização para copiar aquilo que fosse do seu interesse, porém, deve ter demonstrado preocupação tanto com a permanência do manuscrito nas mãos do sócio do IHGB, como com as condições de armazenamento às quais o códice estava submetido, haja vista o tom tranquilizador no qual Varnhagen redigiu resposta em 25 de maio de 1842: "Sobre o seu livro das Minas esteja descansado que está seguro. Estou a aproveitar delle coisas para que nem sempre tenho tempo. Porém, não é coisa que se possa perder na Babylonia do meu quarto, que agora está muito arranjado". ${ }^{38}$

Fato é que as missivas mencionadas permitem constatar não só quando Varnhagen entrou em contato com o códice das Notícias Práticas, mas também que o historiador esteve com ele pelo menos de abril a maio do mesmo ano em seu próprio aposento. Sabemos igualmente que os registros e as cópias feitas por ele foram mobilizados posteriormente na publicação da $1^{a}$ notícia prática na Revista do Instituto ${ }^{39}$ e na redação do capítulo "Outros factos e providencias até 1750. Ouro e Diamantes", do tomo segundo de História Geral do Brazil (1857), no qual todas as notícias, com exceção da $8^{a}$, foram citadas no corpo do texto ou em nota de rodapé. ${ }^{40}$

Enquanto conseguimos delinear a trajetória da publicação da $1^{a}$ notícia, a documentação compulsada até o momento não nos fornece elementos para acompanhar os trâmites da divulgação da $5^{a}$ notícia de autoria de Antonio Pires de Campos, publicada no tomo 25 da Revista, em 1862.

No corpo do texto não há a indicação do responsável pelo seu oferecimento ao Instituto. ${ }^{41} \mathrm{~A}$ princípio, a hipótese que nos parece mais plausível é a de que o manuscrito tenha sido enviado formalmente não por uma pessoa, mas por meio de um órgão do governo. Isso porque, nas listas de doações de documentos, relatórios e mapas feitos ao IHGB no ano

\footnotetext{
${ }^{36}$ RIVARA, Joaquim Heliodoro da Cunha. Catalogo dos Manuscriptos... Op. cit., p.191-193.

${ }^{37}$ LESSA, Clado Ribeiro da. Correspondência Ativa. Rio de Janeiro: Instituto Nacional do Livro, 1961, p. 74. Grifos nossos.

38 LESSA, Clado Ribeiro da. Correspondência Ativa. Op. cit., p. 76-8.

${ }^{39} \mathrm{Em}$ seu texto, Cabral Camelo menciona que irá dizer "a seu tempo" sobre o episódio da morte do Ouvidor Lanhas Peixoto em decorrência do ataque dos Paiaguá a sua tropa. Varnhagen, em nota de rodapé, escreve: "O informante refere-se a outra notícia especial que escreveu d'este facto, e que publicaremos logo que obtenhamos a copia que sabemos existir, e que já lemos." Trata-se da $2^{a}$ notícia prática. RIHGB, t. 4, 1842, p. 493.

${ }^{40}$ VARNHAGEN, Francisco Adolfo de. História Geral do Brazil. Madrid: Imprensa de J. del Rio, 1857, t. 2, p. 161-186.

${ }^{41}$ Infelizmente essa notícia não é precedida por nota que esclareça a origem do manuscrito.
} 
de 1862 , os únicos conjuntos nos quais caberia o relato em questão são quatro volumes de manuscritos de Évora - sem indicação alguma dos conteúdos - feita pela Secretaria de Estado dos Negócios do Império. ${ }^{42}$

Pela edição das narrativas no periódico bem se vê como a preocupação com os limites territoriais - que desencadearia a guerra contra o Paraguai mais à frente - trouxe consigo a recuperação das narrativas monçoeiras. A iniciativa do Estado imperial em se munir de documentação relativa a Mato Grosso - a fim de subsidiá-lo na demarcação de fronteiras para a defesa da soberania do país - foi tanta que nos primeiros trinta anos da Revista do Instituto Histórico e Geográfico Brasileiro há mais de cinquenta publicações concernentes à região.

A título de exemplo, mencionamos outros dois textos enviados por Varnhagen: "Relaçaõ da viagem que fez o Conde de Azambuja, D. Antonio Rolim, da Cidade de S. Paulo para a Villa do Cuyabá em 1751" (tomo VII, 1845) e "Compendio histórico chronologico das noticias de Cuyabá, repartição da Capitania de Matto-Grosso. Desde o principio de 1788 até o fim do anno de 1817", por Joaquim da Costa Siqueira (Tomo XIII, 1850). Ainda na década de 1840, destacamos a publicação de "Extracto da Descripção Geographica da Província de Matto Grosso", feita em 1797, por Ricardo Franco de Almeida Serra, Sargento Mór de Engenheiros, oferecido pelo Cônego José da Silva Guimarães (Tomo VI, 1844). Nos anos 1850, selecionamos o "Resumo das explorações feitas pelo engenheiro Luiz D'Alincourt, desde o registro de Camapuã até a cidade de Cuyabá", oferecido L. A. da Cunha Mattos (tomo XX, 1857) e o "Mappa da população da capitania de Matto-Grosso em o anno 1815", elaborado por Antônio Teixeira Cabral (tomo XX, 1857). Por fim, na década de 1860, ressaltamos a impressão das "Observações sobre a carta geographica da província de Matto-Grosso" pelo capitão da fragata Augusto Leverger (tomo XXV, 1862) e a "Exploração da província de Mato Grosso (1863)", registrada por Rodolfo Waehneldt (tomo XXVII parte 1, 1864).

\section{Os relatos monçoeiros no IV Centenário da cidade de São Paulo}

O público só viria a ter contato com as demais Notícias Práticas das Minas de Cuiabá e Goiás na capitania de São Paulo em 1950, quando foram divulgadas por Taunay no tomo XI da História Geral das Bandeiras Paulistas, obra monumental iniciada em 1924, e com a posterior reunião das oito narrativas, feita também por ele, nos chamados Relatos Monçoeiros, a serem comentados adiante. ${ }^{43}$

Em 1952, José de Barros Martins publicava Apontamentos históricos, geográficos, biográficos, estatísticos e noticiosos da província de São Paulo, em dois tomos, de autoria de Manuel Eufrásio de Azevedo Marques, primeiro título da Biblioteca Histórica Paulista, dirigida

\footnotetext{
${ }^{42}$ RIHGB, t. 25, 1862, p.742.

${ }^{43}$ Sobre as bases intelectuais da produção historiográfica e museológica de Taunay, ver sobretudo: ANHEZINI, Karina. Um metódico à brasileira: a História da historiografia de Afonso de Taunay (19111939). São Paulo: Ed. Unesp, 2011; BREFE, Ana Cláudia. Museu Paulista: Affonso de Taunay e a memória nacional 1917-1945. São Paulo: Ed. Unesp; Museu Paulista, 2005.
} 
por Afonso de Taunay. Segundo o próprio editor, não havia poupado esforços ante a necessidade de investir avultado capital para editar velhos textos de nossa paulística, esgotados nas livrarias e bibliotecas, para oferecer como contribuição da Livraria Martins Editora às comemorações do IV Centenário da Fundação de São Paulo. ${ }^{44}$ Em razão da efeméride, todos os dez títulos foram publicados entre 1952 e 1954.

Martins lançou a coleção tendo como referência sua Biblioteca Histórica Brasileira, coordenada por Rubens Borba de Moraes, composta por 18 títulos, editados entre as décadas de 1930 e 1950, e elogiada por trazer aos leitores traduções integrais, cuidadosamente revistas, anotadas e prefaciadas de textos de estrangeiros que visitaram o país e registraram suas impressões. A primeira obra lançada naquela coleção, em 1939 - no mesmo ano da fundação da editora - fora Viagem pitoresca através do Brasil, de Rugendas, ilustrada com 100 gravuras da edição original e mais 10 de coleções particulares. O cuidado gráfico presente desde a primeira obra foi, na verdade, a marca da editora paulista ao longo de seus 35 anos de existência, revelado inclusive nas capas criadas por artistas do quilate de Di Cavalcanti, Tarsila do Amaral, Anita Malfatti e José Wasth Rodrigues. ${ }^{45}$

A maior parte dos títulos da Biblioteca Histórica Brasileira carregava "Brasil" no título, como a demonstrar a abordagem do território numa perspectiva exógena e mais ampla. Já a Biblioteca Histórica Paulista tem seu núcleo formado por textos que versam sobre São Paulo, capitania e província. Ademais, conta com autores da terra ou naturalizados, como Azevedo Marques, Augusto Emilio Zaluar, Pedro Taques de Almeida Paes Leme, Frei Gaspar da Madre de Deus, os monçoeiros e sertanistas que deixaram suas notícias práticas.

Para a coordenação da Biblioteca Histórica Paulista, Martins chamara Afonso de Taunay que havia dirigido o Museu Paulista de 1917 a 1945 e publicado inúmeras obras sobre o passado paulista, entre as quais a monumental História Geral das Bandeiras Paulistas, em 11 volumes, que the consumira décadas de pesquisa, reunião de documentos e escrita até a finalização em 1950. Segundo o editor, Taunay era o "homem mais capaz para dirigir e orientar uma Biblioteca Histórica Paulista". ${ }^{46}$

Embora não tenha integrado a Comissão do IV Centenário, Taunay fora convidado pelo seu presidente, Francisco Matarazzo Sobrinho, para fazer parte de várias consultorias técnicas, que eram órgãos honoríficos da autarquia, constituídas por elementos de destaque na vida intelectual e social paulistana. ${ }^{47}$ Também recebera convite de outras instituições que se mobilizaram em função do IV Centenário, como o Instituto Histórico e Geográfico de São Paulo, que o nomeou junto a Washington Luís para compor a Comissão de Honra com a qual o

\footnotetext{
${ }^{44}$ MARTINS, José de Barros. Palavras do editor. In: Catálogo da Biblioteca Histórica Paulista. São Paulo: Livraria Martins Editora, [s.d.]

${ }^{45}$ PONTES, Heloísa. Retratos do Brasil: um estudo dos editores, das editoras e das coleções brasilianas, nas décadas de 1930, 40 e 50. In: MICELI, Sérgio (org.). História das Ciências Sociais no Brasil. São Paulo: Vértice, 1989, p. 383.

${ }^{46}$ Entrevista de José de Barros Martins. FLAN: O Jornal da Semana, Rio de Janeiro, ed. 31, 1953.

${ }^{47}$ Cartas de 09/04/1952, 30/07/1952 e 14/08/1953 enviadas por Francisco Matarazzo Sobrinho a Afonso Taunay. Museu Paulista/USP, Serviço de Documentação Histórica e Iconografia, Arquivo Permanente, Coleção Afonso Taunay, pasta 23.
} 
Instituto se apresentaria no Congresso de História dos festejos; a Secretaria de Educação de Adultos, que lhe solicitou um artigo sobre o desenvolvimento do ensino primário e supletivo em São Paulo desde os seus primórdios; o Congresso Internacional de História, que o convidou por meio de Eduardo D’Oliveira França (na condição de secretário do Brasil no Congresso) para que integrasse o evento. ${ }^{48}$ Ademais, Taunay foi responsável pela organização da obra coletiva São Paulo em quatro séculos, publicada em 2 volumes, em 1953 e 1954, sob os auspícios daquela Comissão.

Para além do renome que Taunay desfrutava no cenário intelectual, sabemos que ele e Martins mantiveram contato quando o editor esteve à frente do Departamento Municipal de Cultura de São Paulo, de 1949 a 1950, a fim de acordarem prazos para redação de livro. ${ }^{49}$

A Biblioteca Histórica Paulista era formada por dez títulos, sendo sete deles reedições de obras sobre o passado paulista e três ainda inéditos (os volumes VII, IX e X). São eles: Vol. I. Apontamentos históricos, geográficos, biográficos estatísticos e noticiosos da província de São Paulo, de Manuel Eufrasio de Azevedo Marques; Vol. II. Peregrinação pela província de São Paulo (1860-1861), de Augusto Emílio Zaluar; Vol.III. Memórias para a história da capitania de S. Vicente, de Frei Gaspar da Madre de Deus; Vol. IV. Nobiliarchia paulistana história e genealógica, de Pedro Taques de Almeida Paes Leme; Vol. V. Viagem às províncias do Rio de Janeiro e São Paulo, de Johann Jakob von Tschudi; Vol. VI. Segunda viagem à São Paulo e quadro histórico da província de São Paulo. Augusto de Saint-Hilaire; Vol. VII. Relatos Sertanistas, editado por Afonso Taunay; Vol. VIII. Memória sobre a viagem do porto de Santos à cidade de Cuiabá, de Luiz D’Alincourt; Vol. IX. Relatos Monçoeiros, editado por Afonso Taunay; Vol. X. Notícias das minas de São Paulo e dos sertões da mesma capitania, de Pedro Taques de Almeida Paes Leme.

A iniciativa coadunava-se com um dos principais propósitos da Comissão do IV Centenário: "promover estudos históricos relativos à fundação de São Paulo (...) bem como reeditar obras históricas em geral, referentes à evolução política, econômica e cultural de São Paulo", ${ }^{50}$ tanto é que a Comissão decidira publicar a sua própria Biblioteca, nomeada Biblioteca do IV Centenário, cujo primeiro volume foi o Dicionário de Bandeirantes e Sertanistas do Brasil, de Francisco de Assis Carvalho Franco.

\footnotetext{
${ }^{48}$ Carta de Ernesto Souza Campos e Tito Lívio Ferreira, presidente e secretário geral do IHGSP a Afonso Taunay. (14/03/1953); Carta de Lázaro Gonçalves Teixeira, diretor do Serviço de Educação de Adultos a Afonso Taunay (20/04/1953); Carta de Eduardo D'Oliveira França a Afonso Taunay (21/05/1953). Museu Paulista/USP, Serviço de Documentação Histórica e Iconografia, Arquivo Permanente, Coleção Afonso Taunay, pasta 23.

${ }^{49}$ A carta não possui data, porém, Martins é tratado como diretor do Departamento de Cultura da Cidade de São Paulo, cargo que ocupou entre 1949 e 1950. A obra em questão é História da Cidade de São

Paulo, encomendada pelo então prefeito Abrahão Ribeiro. Taunay solicita a Martins a prorrogação do prazo de entrega em 2 anos, assim como propõe a continuidade da obra com a escrita de um novo volume que abarque temporalmente a Independência e os primeiros anos do Império. Museu Paulista/ USP, Serviço de Documentação Histórica e Iconografia, Arquivo Permanente, Coleção Afonso Taunay, pasta 23.

${ }^{50}$ Portaria 8, artigo 50, letra B - Prefeitura de São Paulo, 6 de abril de 1949 apud LOFEGO, Silvio Luiz. 1954 - A cidade aniversariante e a memória coletiva. O IV Centenário da Cidade de São Paulo. Projeto História, São Paulo, n. 20, abr. 2000, p. 308.
} 
A temática escolhida para inaugurar a coleção oficial, em 1953, já indica o esforço da Comissão em projetar por meio da literatura a figura do passado que serviria como alicerce para a identidade paulista que se procurava forjar em meio à pluralidade de habitantes que compunham a cidade. Tal personagem mais uma vez foi o bandeirante, mas não aquele vinculado exclusivamente ao sertanismo, aos primeiros troncos da terra, dos quais se depreende noção de nobiliarquia, de herança constituída por laços de sangue. Antes, o bandeirante adjetivo, tomado enquanto aquele que qualifica feitos e espíritos e que simboliza heroísmo, intrepidez, pioneirismo, bravura, empreendedorismo, podendo congregar em sua filiação gentes de outras partes do Brasil, de raízes estrangeiras, trabalhadores e empresários em um mesmo solo, a cidade de São Paulo. ${ }^{51}$

No caso da Biblioteca Histórica Paulista, da Livraria Martins, a própria materialidade da coleção remete ao passado seiscentista paulista. José Wasth Rodrigues foi responsável pela ilustração da capa e pela estampa comemorativa da coleção. Ninguém mais apropriado que ele, que já havia sido autor de várias telas encomendadas por Afonso de Taunay, durante sua gestão à frente do Museu Paulista, e era ilustrador da Livraria Martins. E foi de seu trabalho nessas duas instituições que Wasth Rodrigues criou as marcas da coleção ligadas ao bandeirismo, pois foram retiradas de seus próprios desenhos na obra Vida e morte do bandeirante, de Alcântara Machado, publicado pela Martins, em 1943.

\footnotetext{
51 Sobre a criação das imagens do bandeirante nas festividades de 1954, ver MARINS, Paulo César Garcez. O Parque do Ibirapuera e a construção da identidade paulista. Anais do Museu Paulista, São Paulo, v. 6-7, 9-36, 1998-1999; LOFEGO, Silvio Luiz. IV Centenário da Cidade de São Paulo: uma cidade entre o passado e o futuro. São Paulo: Annablume, 2004. Já para a construção do mito do bandeirante pela elite paulista desde o último quartel do século XIX até os anos de 1940, no período que antecedeu as efemérides do IV Centenário, ver: ABUD, Katia Maria. O sangue intimorato e as nobilíssimas tradições: a construção de um símbolo paulista, o bandeirante. 1986. Tese (Doutorado em História) - Universidade de São Paulo, São Paulo; FERREIRA, Antonio Celso. A epopéia bandeirante: letrados, instituições, invenção histórica (1870-1940). São Paulo: Ed. UNESP, 2002.
} 
Figura 1 e 2 - Capa e estampa comemorativa da $1^{\text {a }}$ edição de Relatos Monçoeiros
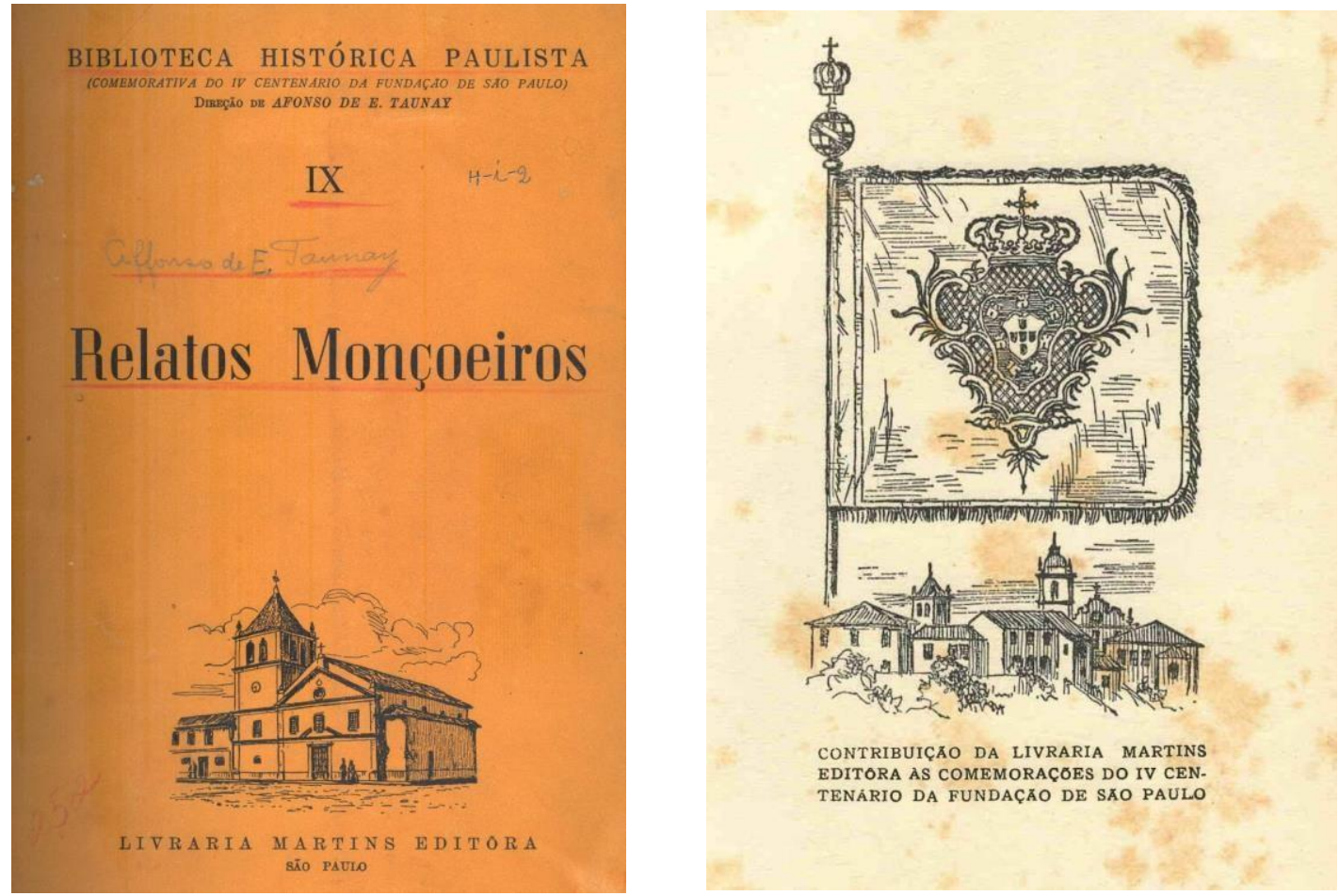

Fonte: TAUNAY, Afonso de E. Relatos Monçoeiros. São Paulo: Livraria Martins Editora, 1953.

A ilustração da capa é uma estampa da Igreja do Colégio, que abriu o capítulo Educação e cultura, do Vida e morte do bandeirante, em total sintonia com as referências primordiais para a coleção que se estava lançando. E o emblema da coleção, que é o estandarte da cidade de São Paulo do século XVII, século do bandeirismo, encimando a vista da cidade a partir da várzea do Carmo, abriu, por sua vez, o capítulo "As devoções dos bandeirantes", também do livro de Alcântara Machado. 
Figuras 3 e 4 - Estampas de abertura dos capítulos "Educação e Cultura" e "As devoções dos bandeirantes" em Vida e Morte do Bandeirante.
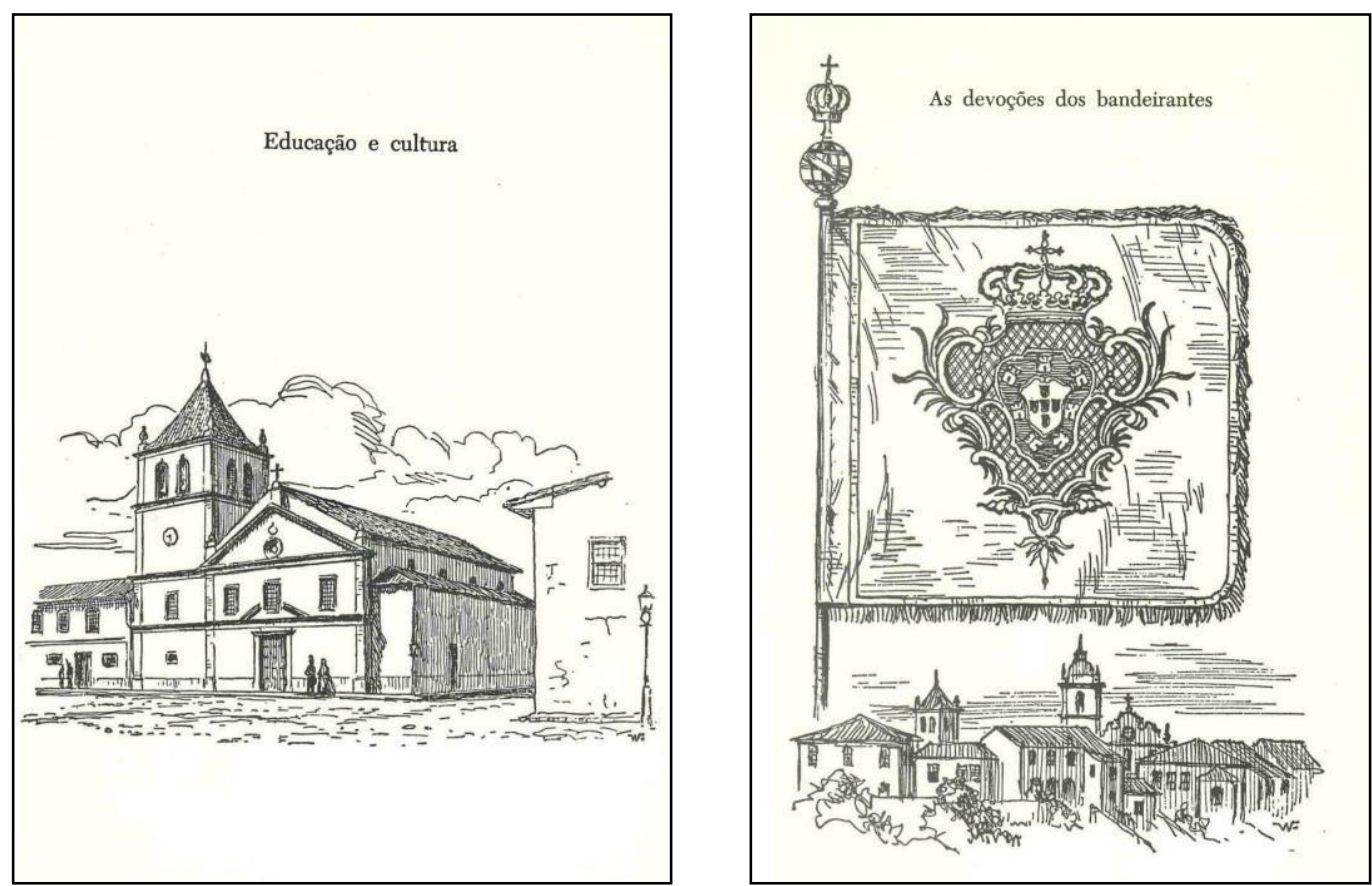

Fonte: MACHADO, Antonio de Alcântara. Vida e Morte do Bandeirante. São Paulo: Livraria Martins Editora, 1943.

Tal estandarte já fora ilustrado por Wasth Rodrigues em Brazões e Bandeiras do Brasil, de Clóvis Pereira, publicado em 1933. Todavia nessa obra, a bandeira, que é uma cópia exata do brasão de $D$. João $V$, figura sem a esfera armilar e a coroa do Império do Brasil no topo do mastro.

Figura 5 - Detalhe dos brasões desenhados por J. W. Rodrigues. Destaque para o brasão de número IX, de D. João $\mathrm{V}$

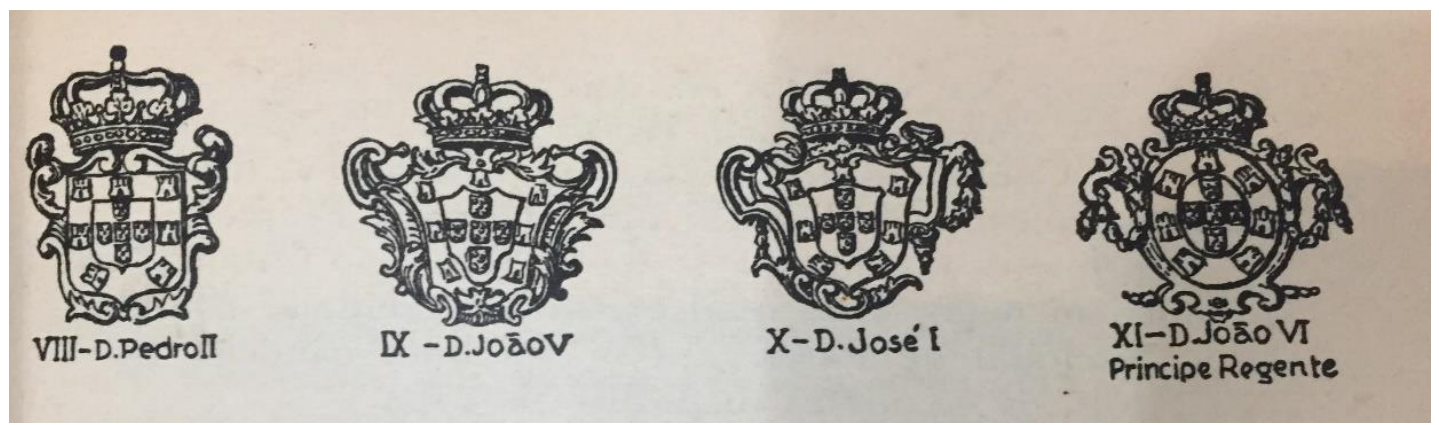

Fonte: PEREIRA, Clovis. Brazões e Bandeiras do Brasil. São Paulo: São Paulo Editora, 1933, p. 85. 
Tanto em Brazões e Bandeiras, como em Vida e morte do bandeirante, nos créditos das ilustrações, há a menção ao exemplar guardado no acervo do Museu Paulista, que teria sido usado como estandarte do Senado da Câmara de São Paulo, datado de finais do século XVIII. Esse artefato teria pertencido ao Brigadeiro Luis Antonio de Souza Queiroz, uma das maiores fortunas do início dos oitocentos paulista e fora doado à instituição por sua neta, D. Francisca Miquelina de Sousa Queiroz, em 1923. ${ }^{52}$

Figura 6 - Estandarte da Câmara Municipal de São Paulo

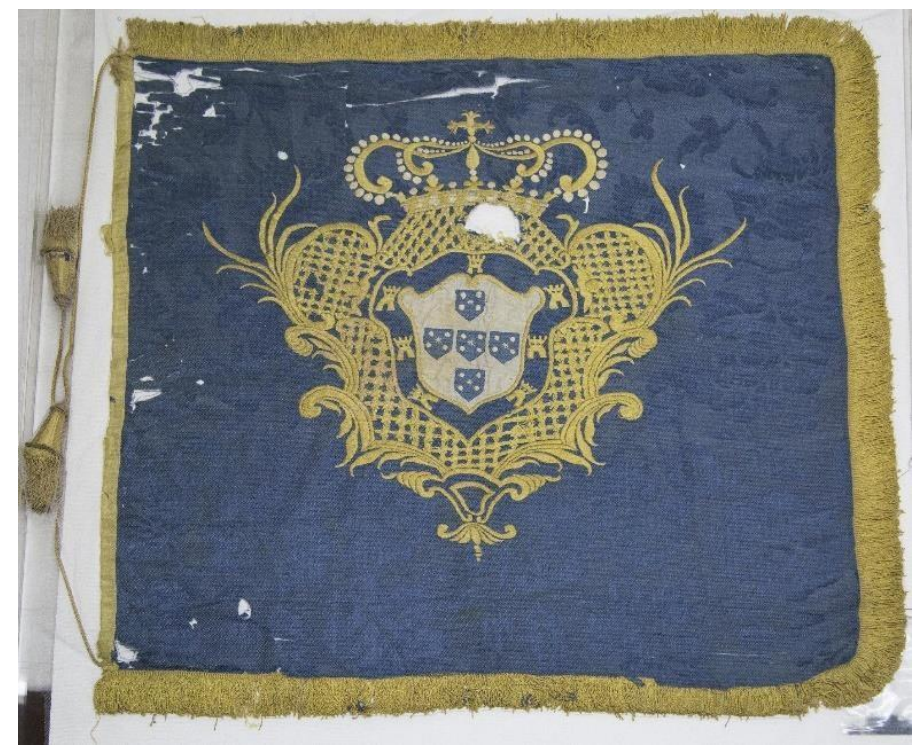

Fonte: Serviço de Objetos, Museu Paulista/USP. Foto: José Rosael.

Os livros da Biblioteca Histórica Paulista, publicados pela Martins, tinham 23,5 cm de altura e 16,5 cm de largura e foram impressos, em suas versões capa mole e, de luxo, em capa dura, nas Empresas da Oficina Gráfica da Revista dos Tribunais, cujos equipamentos haviam sido comprados da editora de Monteiro Lobato, quando de sua falência. ${ }^{53}$ Todos traziam estudos introdutórios e eram ilustrados.

Ainda que lançasse uma coleção literária própria, a Biblioteca do IV Centenário, a Comissão acabou por subvencionar uma edição dos títulos da Biblioteca Histórica Paulista, publicando-os no mesmo período que a Martins, com outras capas e estampas comemorativas, com os dizeres "Publicações comemorativas sob o alto patrocínio da Comissão do IV Centenário da Cidade de São Paulo".

Em 1976, em razão do cinquentenário das atividades da Empresa Gráfica Revista dos Tribunais, a Biblioteca Histórica Paulista ganhou nova edição e, tal como a Biblioteca Histórica

\footnotetext{
${ }^{52}$ RELATÓRIO anual referente ao ano de 1923. Revista do Museu Paulista, 1926, v. 14.

${ }^{53}$ HALLEWELL, Laurence. O Livro no Brasil: sua história. 3aed. São Paulo: Ed. USP, 2012, p. 389-92.
} 
Brasileira, foi integralmente publicada na Série Reconquista do Brasil e Reconquista do Brasil (nova série), nas décadas de 1970 e 1980, pela Editora Itatiaia e Edusp. ${ }^{54}$

O volume dedicado aos Relatos Monçoeiros é composto por estudos introdutórios de autoria de Taunay que ocupam $1 / 3$ do total da obra e pela publicação integral de 13 relatos, dos quais 8 fazem parte do códice CXVI 1-15 da Coleção Diogo Soares, inseridas no grupo Notícias práticas das Minas de Cuiabá e Goiás na capitania de São Paulo, pertencente à Biblioteca Pública de Évora. Os demais grupos compostos por notícias práticas de outras regiões da América Portuguesa passaram a integrar os Relatos Sertanistas.

Segundo o próprio Taunay, foi por meio da obra História da Companhia de Jesus no Brasil, em especial seu volume 9, publicado em 1949, que ele tomou conhecimento da existência de notícias práticas ainda manuscritas em Évora, pois, nesse volume, dedicado aos escritores jesuítas de $\mathrm{N}$ a Z , Serafim Leite traçara uma biografia de Diogo Soares e elencara a bibliografia do jesuíta matemático. "Percorrendo-a deparou-se-nos o ensejo de notar que das Notícias Práticas há algumas ainda, manuscritas, conservadas na Biblioteca de Évora".55

Surpreendente é o fato de Taunay ter descoberto notícias práticas monçoeiras inéditas apenas no final da década de 1940, a partir da leitura de Serafim Leite, quando na verdade, Varnhagen, em História Geral do Brazil, fosse no corpo do texto, fosse em notas de rodapé, havia mencionado a existência de sete das oito notícias práticas concernentes a Cuiabá, ${ }^{56}$ como comentamos anteriormente.

A partir dessa constatação, Taunay passou a mobilizar contatos em Portugal para que tais notícias fossem copiadas e enviadas para o Brasil, o que o inspirou a escrever a segunda parte do tomo XI de História Geral das Bandeiras Paulistas. ${ }^{57}$ Entretanto, nesse tomo, Taunay não as publicou integralmente, intercalando trechos das notícias com sua própria narrativa, sempre sinalizados por aspas.

A novidade, portanto, da publicação dos Relatos Monçoeiros em relação ao tomo XI foi apresentar cada uma das Notícias Práticas individualmente. Ele desmembrou seu próprio texto da História Geral das Bandeiras Paulistas: o que era de sua autoria foi deslocado para o início do volume como estudo com poucas modificações, como a retirada de parágrafos e frases para dar coerência ao texto; o que era conteúdo das Notícias Práticas foi particularizado e expandido na segunda parte do volume, respeitando a numeração dada pelo próprio Diogo Soares no códice guardado em Évora.

\footnotetext{
${ }^{54}$ Sobre a reedição das coleções Biblioteca Histórica do Brasil e Biblioteca Histórica Paulista pelas editoras Itatiaia e Edusp, ver: SERRANO, Gisella de Amorim. Memória e História na Coleção Reconquista do Brasil: Minas no Brasil. Outros Tempos, v. 11, p.280-294, 2014.

55 TAUNAY, Afonso. História Geral das Bandeiras Paulistas. São Paulo: Imprensa Oficial do Estado, 1950, tomo XI, p. 31.

${ }^{56}$ VARNHAGEN, Francisco Adolfo de. Op.cit, t. 2, p. 169-172.

${ }^{57}$ Registra no prefácio ao tomo XI os seus agradecimentos ao Dr. Armando Nobre de Gusmão (diretor da Biblioteca de Évora), ao Dr. Urbano Canuto Soares (prof. da USP), Dr. Murilo Bastos (secretário da embaixada do Brasil em Lisboa) e José Pinto da Fonseca (Instituto Biológico de São Paulo) pelos "excelentes serviços que me prestaram para a obtenção, remessa de reprodução desse contingente de origem eborense". TAUNAY, Afonso. História Geral..., p. 15.
} 
Em realidade, parte do conteúdo autoral dos estudos introdutórios de Relatos Monçoeiros conta com o aproveitamento de textos escritos por Taunay desde a década de 1920. A "Introdução" desta obra (1953) contém grande parte do capítulo 1, da $2^{a}$ parte do tomo XI de História Geral das Bandeiras Paulistas (1950), intitulado "O Tietê, instrumento máximo de penetração do Brasil sul ocidental" que, por sua vez, foi publicado no Jornal do Commercio, de 23 de janeiro de 1944, com o título "A grande via secular de Oeste", o qual tivera como matriz parte do discurso proferido por ele próprio na inauguração do Monumento às Monções, em 26 de abril de 1920, em Porto Feliz, impresso posteriormente como À glória das monções. ${ }^{58}$

Todavia, é importante ressaltar que as notícias práticas apresentadas nos Relatos Monçoeiros possuem diferenças significativas em relação aos excertos citados entre aspas por Taunay no tomo XI da sua História Geral das Bandeiras Paulistas, não só no que diz respeito à grafia, acentuação e pontuação, mas também a acréscimo e/ou supressão de trechos. A título de exemplo, em uma única notícia, a 6a, dada por Gervásio Leite Rebelo, há casos como os seguintes:

Quadro 4 - Comparação entre trechos da 6a notícia prática publicada na História Geral das Bandeiras Paulistas (1950) e nos Relatos Monçoeiros (1953)

\begin{tabular}{|c|c|}
\hline & Relatos Monçoeiros \\
\hline $\begin{array}{l}\text { "Neste varadouro de canôas e cargas, morte } \\
\text { de brancos e negros, consumo de } \\
\text { mantimentos e destruição de tudo e a que } \\
\text { com razão se pode chamar a Linha (s.c. a } \\
\text { equatorial) desta viagem se dilatou a tropa } \\
\text { por onze dias". }{ }^{59}\end{array}$ & $\begin{array}{l}\text { "Neste varadouro de canoas e cargas, morte } \\
\text { de brancos e negros, consumo de } \\
\text { mantimentos e destruição de tudo, a que } \\
\text { com razão se pode chamar linha desta } \\
\text { viagem, se dilatou a tropa onze dias } \\
\text { assim". }{ }^{60}\end{array}$ \\
\hline $\begin{array}{l}\text { suas armas, de } \\
\text { tro, em campo } \\
\text { folhetas e grãos } \\
\text { na, uma Fenis". }\end{array}$ & $\begin{array}{l}\text { "e se declarou seriam as suas armas, de } \\
\text { quem usasse um escudo, e dentro em campo } \\
\text { verde um morro coberto de folhetas e grãos } \\
\text { de ouro, e por timbre em cima uma Fenis". }\end{array}$ \\
\hline $\begin{array}{l}\text { "na secretaria do governo, por ordem do } \\
\text { Exmo. Rodrigo Cesar de Menezes, } \\
\text { Governador e Capitão General desta } \\
\text { Capitania, e suas Minas, em virtude das } \\
\text { ordens que teve de sua Magestade para } \\
\text { passar a elas e criar vila ao dito arrayal a } \\
\text { que deu seu cumprimento". }{ }^{63}\end{array}$ & $\begin{array}{l}\text { "na secretaria dêste govêrno por ordem do } \\
\text { Exmo Sr. Rodrigo Cesar de Meneses, } \\
\text { Governador e Cap General desta Capitania, e } \\
\text { suas Minas em virtude das Ordens que teve } \\
\text { de Sua Majestade para passar a elas e criar } \\
\text { Va ao do arraial; a que deu cumprimento na } \\
\text { forma já declarada". }{ }^{64}\end{array}$ \\
\hline
\end{tabular}

\footnotetext{
58 TAUNAY, Afonso. À glória das monções. São Paulo: Casa Editora "O Livro", 1920.

59 TAUNAY, Afonso de E. História Geral ..., p. 40.

60 TAUNAY, Afonso de E. Relatos Monçoeiros. Op. cit, 1953, p. 106.

61 TAUNAY, Afonso de E. História Geral... Op. cit. , p. 46.

62 TAUNAY, Afonso de E. Relatos Monçoeiros. Op. cit., 1953, p. 113.

63 TAUNAY, Afonso de E. História Geral... Op. cit., p. 46.

${ }^{64}$ TAUNAY, Afonso de E. Relatos Monçoeiros. Op. cit., 1953, p. 113.
} 
Sabe-se, pela menção feita no tomo XI, que Taunay não teve acesso direto aos manuscritos em Évora, logo, a transcrição que Ihe serviu de matriz para História Geral das Bandeiras Paulistas e para os Relatos Monçoeiros foi realizada por outra pessoa. Disso deriva o questionamento sobre a partir de qual dos dois testemunhos - o de Diogo Soares ou o do escriba desconhecido - a transcrição foi realizada. Ou teriam sido ambos mobilizados indistintamente?

Embora Taunay tenha o grande mérito de trazer a público relatos produzidos na primeira metade do século XVIII sobre as viagens pelos rios que se realizavam entre Porto Feliz (São Paulo) e Cuiabá (Mato Grosso), ao colocá-las na segunda parte do último tomo de História Geral das Bandeiras Paulistas, elas acabaram por figurar como um capítulo derradeiro das bandeiras, o que reforçou a associação entre ambas, evidenciada em suas próprias palavras: "Criara-se o episódio das monções, inserto com o maior relevo nos anaes do bandeirantismo de São Paulo, assumido [sic] ímpar originalidade não só em nossos fastos nacionais como nos do Universo". ${ }^{65}$

Nos estudos introdutórios dos relatos monçoeiros e nos artigos de jornal de autoria de Taunay, datados de 1920 a $1944,{ }^{66}$ tal associação fica evidente pelo menos por dois fatores. O primeiro relacionado à ocupação dos sertanistas na região do Mboteteú, desde finais do século XVII, que teria sido responsável pela descoberta aurífera na região oeste da América Portuguesa. ${ }^{67}$ $\mathrm{E}$, o segundo, ao vincular a diminuição das monções com a queda da produção aurífera nas minas de Cuiabá. ${ }^{68}$ Entretanto, ele próprio admitiu a continuidade das viagens até os inícios do século XIX, quando partiu, de Porto Feliz, a expedição científica do Barão de Langsdorff. ${ }^{69}$

Foram justamente a permanência ao longo de todo século XVIII e a regularidade anual das viagens os fatores que fizeram com que Sérgio Buarque de Holanda, logo na primeira edição de Monções, publicada em 1945, dissociasse as chamadas monções de povoado da história das bandeiras, atrelando-as à atividade mercantil, tanto que em Caminhos e fronteiras, lançado em 1957, intitulou o capítulo dedicado a essas expedições fluviais de Frotas de comércio. $^{70}$ Silvana Godoy, Maria Glória Kok e Tiago Kramer de Oliveira também dissociaram as monções das bandeiras, tanto pela questão da atividade agropastoril realizada ao longo dos caminhos fluviais para o fornecimento de víveres e gado para as expedições

\footnotetext{
65 TAUNAY, Afonso de E. Relatos Monçoeiros. Op. cit., 1981, p. 17.

${ }^{66}$ Durante toda vida, Afonso de Taunay fez uso dos jornais de grande circulação, sobretudo no Rio de Janeiro e São Paulo, para difundir suas pesquisas sobre bandeiras e monções. No Jornal do Commercio, por exemplo, publicou "Os paulistas no sul do Matto Grosso" (08/12/1929); "Causas de Mato-Grosso" (30/04/1939) e "A grande via secular de Oeste" (23/01/1944).

67 "Certo é que alguns annos após 1680, vivia Paschoal Moreira Cabral Leme, então moço de seus vinte e muitos annos, como fronteiro de Mboteteu a ensaiar a marcha para o Norte de que resultaria a posse de Cuyabá". TAUNAY, Afonso. Os paulistas e a conquista do sul do Mato Grosso. Jornal do Commercio, Rio de Janeiro, 10 nov. 1929.

68 "Caem em declínio as minas de Cuiabá e escasseiam as monções, mas nem por isto deixa a navegação do Tietê de existir". TAUNAY, Afonso. Relatos Monçoeiros. Op. cit., 1981, p. 15.

${ }^{69}$ As viagens fluviais deixam, então, de serem denominadas monções, para serem mencionadas como expedições, embarques.

70 HOLANDA, Sérgio Buarque de. Monções e Capítulos de Expansão Paulista. Org.: Laura de Mello e André Sekkel Cerqueira. 4a ed. São Paulo: Companhia das Letras, 2014; HOLANDA, Sérgio Buarque de.

Caminhos e Fronteiras. Op. cit.
} 
monçoeiras, quanto pelas atividades mercantis praticadas pelos cuiabanos, como eram chamados os passageiros das monções para o Cuiabá. ${ }^{71}$

Ao considerar as monções como um capítulo das bandeiras, desprovendo-as de suas especificidades e natureza própria, corre-se o risco de obscurecer outros atores sociais do passado paulista sob o manto do bandeirismo, como buscou fazer tanto a Comissão do IV Centenário ao proceder à construção simbólica do bandeirante como denominador comum de uma cidade plural e heterogênea, como a Biblioteca Histórica Paulista ao trazer o estandarte da cidade colonial como estampa de uma São Paulo de múltiplas temporalidades como retratada nos livros da coleção Biblioteca Histórica Paulista, da qual Relatos Monçoeiros fazia parte.

\section{À guisa de conclusão}

A ausência da indicação dos critérios utilizados na edição dos Relatos Monçoeiros, o reconhecimento da existência de mais de um testemunho das Notícias Práticas no códice CXVI 1-15, assim como a constatação de variações que ultrapassam o nível da atualização de grafia e de pontuação nos textos trazidos a público justificam a realização de uma nova edição do conjunto das oito notícias. Orientada pelos princípios contemporâneos da Crítica Textual e amparada por perspectivas analíticas da História, tal empreitada buscará tanto fixar um texto o mais próximo possível do original como considerar a biografia cultural do conjunto documental em questão nas várias fases de sua vida social. ${ }^{72}$

Ao percorrermos os itinerários das Notícias Práticas das Minas de Cuiabá e Goiás na capitania de São Paulo, as observamos em três contextos de produção e apropriação distintas. Cada um deles correspondeu a momentos-chave da definição de fronteiras geográficas ou simbólicas do território em que as narrativas monçoeiras foram mobilizadas. Primeiramente, para fazer frente ao avanço dos colonos da América hispânica na primeira metade dos setecentos $^{73}$; em seguida, para auxiliar o Estado monárquico no jogo de xadrez da geopolítica tanto externa - na questão dos limites com os países vizinhos - como interna - na questão da

\footnotetext{
${ }^{71}$ GODOY, Silvana Alves de. Itu e Araritaguaba na Rota das Monções (1718-1838). 2002. Dissertação (Mestrado em História Econômica) - Instituto de Economia da Universidade Estadual de Campinas, Campinas; KOK, Glória. O sertão itinerante: expedições da capitania de São Paulo no século XVIII. São Paulo: Hucitec; Fapesp, 2004; OLIVEIRA, Tiago Kramer de. O capital mercantil no centro da América do Sul e as fronteiras do comércio na América colonial (primeira metade do século XVIII). Revista de Indias, v. LXXV, n. 265, 681-710, 2015; Idem. Roças, fazendas, engenhos, currais: uma cartografia da ruralidade colonial nas minas do Cuiabá ( $1^{a}$ metade do século XVIII). Revista de História (São Paulo), $\mathrm{n}$. 173, 211-251, jul./dez. 2015.

72 Expressões emprestadas de Igor Kopytoff e Arjun Appadurai. KOPYTOFF, Igor. A biografia cultural das coisas: a mercantilização como processo. In: APPADURAI, Arjun (org.). A vida social das coisas: as mercadorias sob uma perspectiva cultural. Niterói: Ed. UFF, 2008, p. 89-142.

${ }^{73}$ ALMEIDA, André Ferrand. A formação do espaço... Op. cit.
} 
centralidade da capital e subordinação das demais províncias ${ }^{74}$; e, por fim, para engrandecer o passado expansionista paulista, fortalecendo a imagem grandiosa da cidade de São Paulo que os atores políticos e econômicos procuravam construir, em meados do século XX, outorgandoIhe primazia no cenário nacional. ${ }^{75}$

Ao longo de mais de dois séculos tivemos punhos emprestados responsáveis pela confecção das Notícias Práticas que thes deram sentidos e usos específicos: os de Domingos Lourenço de Araujo que anotou o relato de Antonio Pires de Campos; os do padre Diogo Soares ao homogeneizar as narrativas com sua letra, ordenando-Ihes e produzindo um códice; os de Varnhagen, que descobriu os dois testemunhos em Évora; os do paleógrafo que transcreveu as notícias a pedido de Afonso de Taunay e os do próprio Taunay ao recortá-las no tomo XI da História Geral das Bandeiras Paulistas e ao publicá-las individualmente no Relatos Monçoeiros. Tal variedade de mãos demonstra como a questão da autoria dos relatos não se pode restringir à primeira redação, mas antes devem ser considerados aqueles que compuseram, aqueles que copiaram e aqueles que editaram, como têm salientado Roger Chartier e Fernando Bouza. ${ }^{76}$

Em realidade, os usos e interpretações nos auxiliam a refletir sobre o consumo dos relatos como atos de produção por meio da criação de novos textos e novas formas de leitura de acordo com os interesses distintos dos sujeitos envolvidos e dos contextos em que estavam inseridos. ${ }^{77}$ Nesse sentido, concordamos com Kapil Raj, para quem "circulação não é unicamente o fenômeno do movimento. É o que se passa quando os conhecimentos e as práticas se transformam ao se deslocarem."78

\footnotetext{
${ }^{74}$ RIBEIRO, Renilson. O Brasil inventado pelo visconde de Porto Seguro: Francisco Adolfo de Varnhagen, o Instituto Histórico e Geográfico Brasileiro e a invenção do Brasil Colonial no Brasil Império (18381860). Cuiabá: Entrelinhas, 2015.

75 LOFEGO, Silvio Luiz. IV Centenário da... Op. cit., 2004.

${ }^{76}$ Ao discorrer sobre o manuscrito na era do impresso, Chartier afirma que "a publicação manuscrita mantém assim a ambiguidade do próprio termo 'escritor"'. CHARTIER, Roger. Os desafios da escrita. Op. cit., p. 94. Por sua vez, na discussão sobre a circulação de manuscritos na renovação da história cultural, Bouza comenta que "la copia manuscrita se revela como una forma de transmisión en la que es posible reconocer varias manos y, por tanto, más de un autor". BOUZA, Fernando. Corre manuscrito... Op. cit., p. 21.

77 Segundo Antonio Castillo Gómez "cada acto de consumo o apropiación cultural es también un acto de producción, de creación, es decir, la ocasión para fabricar un texto nuevo aunque éste no se materialice en una práctica de cultura escrita y se queda más bien en la imaginación de cada lector". CASTILLO GÓMEZ, Antonio. Historia de la cultura... Op. cit., p. 121.

${ }^{78}$ SILVA, Matheus Alves Duarte. Circulação não é fluidez - Entrevista com Kapil Raj. Boletim Eletrônico da Sociedade Brasileira de História da Ciência, v.3, p.2, 2016.
} 